\title{
Faces of Evil in Nubian Wall-Painting An Overview
}

\author{
KaRel C. InNEMÉE, Dobrochna ZielińSKa
}

\begin{abstract}
In Christian wall-paintings in Nubia a recurring theme is the struggle between Good and Evil. In this article an overview is given of the various ways in which Evil is depicted or personified, ranging from animals to humans and the hybrid ways in which Satan and his helpers are represented. These different ways have been inspired by sources from a canonical biblical, apocryphal and mythological character.
\end{abstract}

Keywords: Nubia, Christian iconography, mural painting, Devil, warrior saints, Faras, Old Dongola, Banganarti

Karel C. Innemée, University of Amsterdam, Amsterdam / University of Divinity, Melbourne;

k.c.innemee@uva.nl

Dobrochna Zielińska, Institute of Archaeology, University of Warsaw, Warsaw; d.zielinska@uw.edu.pl;

(D) 0000-0003-1870-2994

Good and Evil are abstractions, expressions of ideas concerning moral and social justice and as such they can be considered universal, although the definitions of what is right and wrong differ according to time, religion, and culture. In religious art, which usually has a doctrinal character, representations of good and evil convey a message and very often this message contrasts both powers, depicting the struggle (or balance of power) between the two. This means that Evil is rarely depicted by itself, but usually when it is contrasted, confronted and/or subdued by the powers of Good. Christian art is no exception to this. In the Abrahamic religions there is a dualistic antagonism between Good and Evil and, in the perspective of an eschatological view on history, the expectation that eventually Good will overcome Evil. Although Christian iconography has to be seen as an expression of theological ideas, this article does not aim at going into the extremely complex matter of the origin of Evil in Christian theology, but gives an overview of the variety of ways in which Evil was depicted in Nubian art. This variety includes narrative images, allegorical representations and personifications. 
The Christian concept of Evil is largely based on the Old Testament traditions, but in contrast to God, who appears as a personality, creating heaven and earth, the Devil or Satan and his origin are not mentioned in the first two chapters of Genesis, leaving it to speculation as to whether Evil was created by God or not. ${ }^{1}$ The first episode that refers to the power of Evil is the story of the original sin of Adam and Eve, where the snake is mentioned as ...more subtil than any beast of the field which the Lord God had made ... and punished by God for what he had done (Gen 3:1). ${ }^{2}$ In Genesis 6:1-5 an allusion is made that Evil originates from the 'sons of God' and their interbreeding with mankind, suggesting that these sons of God were angels who had abandoned their spiritual nature.

In the Book of Job (1:7) the same term, 'sons of God' seems to indicate angels, who appear in front of God, among which Satan (litt. 'the adversary, the accuser') is also present, suggesting that Satan is an angel by origin as well. Whose adversary is he? In the story of Job he is the one who challenges and torments Job, while he seems to negotiate with God like a public prosecutor with a judge. Here he is the enemy of humanity, while in other writings he appears in the first place as the opponent of God, while having seduced his people, for instance to worship him under the guise of 'false gods'. The various aspects and different faces of Evil are of course a reflection of the various literary traditions that come together in the Tenakh and the Christian Bible and related apocrypha. Where the Devil, or Satan, and his helpers play a role that is still rather in the background in the New Testament, the Christian tradition from the fourth century onwards seems to develop a demonology, almost with a certain delight, where demons, evil spirits or the Devil himself populate legends and hagiographic texts. Christian iconography in a way reflects the same eagerness in portraying Evil in order to make Virtue stand out in contrast. ${ }^{3}$

It is not mentioned explicitly in the Old Testament that Satan is a fallen angel and the fallen angel who is identified with the morning star (Venus), and is called 'light bearer'

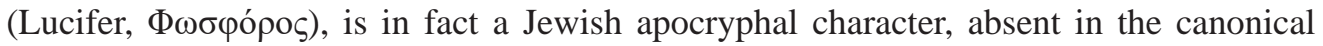
books of the Old Testament, but probably alluded to in Luke 10:18 (And he said unto them, I beheld Satan as lightning fall from heaven). ${ }^{4}$

In these passages Evil takes both a zoomorphic and an anthropomorphic shape and it is only in the Book of Revelation (12:1-9) that these images, the snake and the fallen angel(s) are merged into one representation of Evil. In the final struggle between Good and Evil the Archangel Michael and other angels defeat a dragon 'and his angels' and ...the great dragon was cast out, that old serpent, called the Devil, and Satan, which deceiveth the whole world: he was cast out into the earth, and his angels were cast out with him. In this passage it is made clear that Evil is not a matter of Satan or Lucifer alone, but

${ }^{1}$ As mentioned before, this article is not intended as a theological exegesis of the Old Testament concerning the concept of Evil. For a concise and clear introduction to the Old Testament/Jewish background of Christian beliefs concerning the Devil, see: Schnackenburg, Rahner 1986: 2-4.

${ }^{2}$ In quotations from the Bible the King James Version is used.

${ }^{3}$ Mango 1992.

4 See Jewish Encyclopedia: s.v. Lucifer. 
that there is a hierarchical organisation of Satan and his servants, called angels, also to be identified as demons.

Evil in the Old Testament can also appear in the guise of 'false gods', gods worshipped outside of YHWH, who were not considered to be non-existent, but rather demons in disguise. This makes polytheism a kind of devil-worship, as can be concluded from passages such as Deuteronomy 32:17, Leviticus 17:7, 2 Kings 23. This idea continued in Christianity. The intolerance of Christians towards 'pagan' religions was in fact considered to be a fight against the cult of the Devil and his demons. ${ }^{5}$

The fact that there is not one consistent image of Satan or the Devil has left artists with the liberty to depict him in various forms. He can be represented as a winged human figure, the counterpart of good angels, with a dark colour (dark blue or black) as an indication of his evil character, while his wings can be those of a bat instead of a bird. In the category of zoomorphic representations there is a wide range of animals that can be associated with the Devil: the snake, lion, goat, but also a variety of hybrid and mythological creatures such as dragons, centaurs, and half human, half animal figures. ${ }^{6}$

A remarkable fact is that in Christian art there seems to be no evidence for representations of the Devil, Satan or other creatures depicting Evil before the sixth century, which makes it doubtful whether there is continuity in iconographic tradition with Late Antiquity. The driving out of devils from a possessed man by Christ, a miniature in the Rabbula-codex (AD 586), ${ }^{7}$ and the mosaic of Christ Immanuel trampling on animals in Ravenna seem to be the oldest known examples. ${ }^{8}$

\section{DEPICTIONS OF EVIL IN NUBIA}

In Nubian wall-painting depictions of evil powers occur quite often, in a variety of types. As mentioned above, evil forces are usually shown in a constellation with an opponent that represents the power of God or his representatives. This can be in the context of a symbolical (iconic) or a narrative image and in both cases the message is that Good prevails over Evil, be it in the past or in the future. Evil can be reflected in a number of ways and for a proper understanding of the representations it is important to distinguish between the different ways in which the Devil or his representatives are depicted. A distinction can be made between allegorical and narrative or 'realistic' representations, while such images can refer to the Devil himself or to incarnations of Evil, while a difference should also be made between the Devil himself and his helpers.

${ }^{5}$ Countless incidents of Christian violence against other cults after AD 313 are documented; for the origins and early documents concerning this attitude, see: Borgeaud 2010.

6 Brenk 1990: 295-300.

7 Brenk 1990: 295.

${ }^{8}$ Although the lower part of this representation was restored the reconstruction was based on the iconography of other monuments in Ravenna (Mauskopf Deliyannis 2014: 192, n. 280). For the image, see website: Ravenna. 


\section{Allegorical Images}

An allegorical picture can show a scene that seems to render a realistic image of an actual event, but which is in fact a symbolical representation. The figures in it, be it human or animal, can refer to actual historical characters, but they can also be personifications, visual representations of abstract ideas, such as 'liberty', 'faith' or 'hope'. Vices, virtues, and other personifications have a long tradition as in art. ${ }^{9}$

A typical example of a Christian allegorical type of depiction shows Christ victorious over the forces of Evil, standing on a lion and a snake. This image is based on Psalm 91:13 (Thou shalt tread upon the lion and adder: the young lion and the dragon shalt thou trample under feet). The oldest known example is the above-mentioned mosaic from Ravenna, where Christ is shown in a military outfit with a lion and a snake under his feet. ${ }^{10}$ In later representations, such as the doors of Deir al-Surian and the diptych of Genoels-Elderen, Christ is usually dressed in tunic and pallium. ${ }^{11}$ In this case the snake should not be taken as a physical presence of Satan, as in the case of the snake in Paradise, but as a symbolic image. The text of the psalm concerns the faithful believer, who is protected by God, and Satan is not mentioned, but the lion and snake (in some later representations other animals are present, such as dragon-like creatures) are apparently allegories of the threats that lurk in wild nature and that can threat the life of a human being. This idea, wild animals as the manifestations of untamed nature that threatens human civilisation, can already be found in the iconography of ancient Egypt, Mesopotamia, and the Aegean where the king hunts lions in order to subdue the forces of chaos. The interesting element is here that the lion is on one hand a 'royal' element, associated with kingship itself, and at the same time a symbol of the forces of chaos that have to be tamed. ${ }^{12}$ The imagery of the Old Testament is no exception to this, and the lion appears both as a symbol of (royal) power, as in the case of the heraldry of the Lion of Judah, ${ }^{13}$ and, as in the case of Psalm 91, as a threat to human life.

There is one example of this image known from Nubia, a painting located in Room 3 of House A in Old Dongola and has been previously discussed. ${ }^{14}$ The image represents a standing figure of Christ Emmanuel, trampling on beasts that are depicted as serpent-like animals, visible on both sides of the figure (Fig. 1). The painting is dated to the eight/ninth century AD. This monumental representation was a main mural in a bathing complex that contained two basins provided with hot water. The function of this complex is not clear

9 Famous examples are to be found in the paintings of the monastery of Bawit, such as 'Ecclesia', personification of the Church in Chapelle XVII, Clédat 1904: Pl. XLV.

${ }^{10}$ Although the mosaic has been heavily restored, it seems evident that the lion and the snake were depicted there originally.

11 Innemée 2015: 215-216.

12 Morgan 1995; McMahon 2009.

13 Genesis 49:9: Judah is a lion's whelp: from the prey, my son, thou art gone up: he stooped down, he couched as a lion, and as an old lion; who shall rouse him up?

14 Jakobielski 1979; Godlewski 1982; Górecki 1980: n. 184; Łaptaś 1999; Martens-Czarnecka 2001: 255-258. 
1. Christ trampling on beasts, Old Dongola, House A (Digitally enhanced by D. Zielińska; based on: Godlewski 2013: 106).

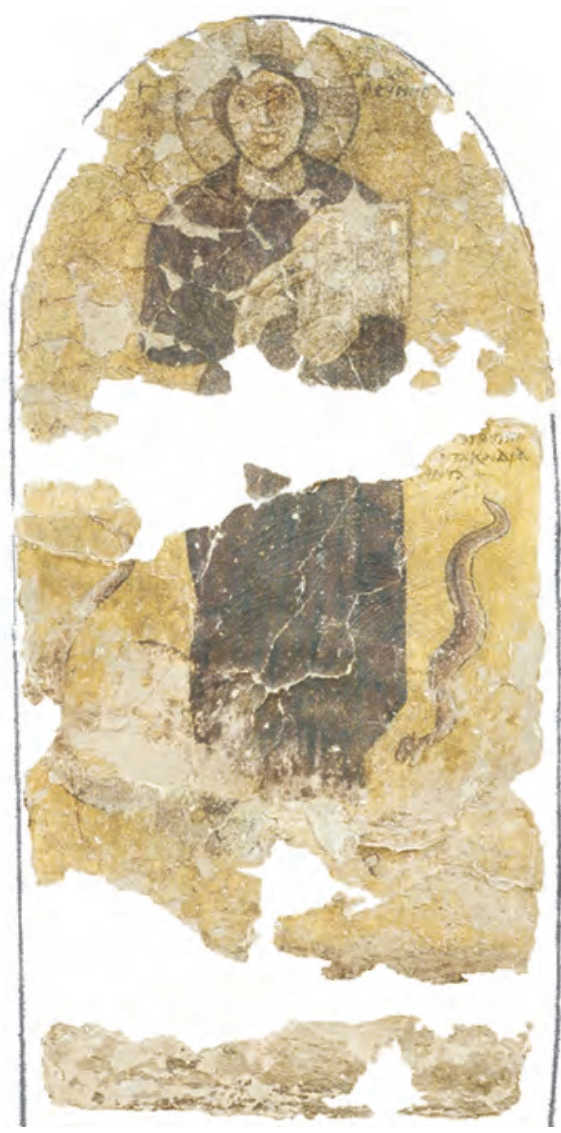

and may be connected with a liturgical/healing purpose. ${ }^{15}$ In that case the imagery may have been meant as an allegory of the power of Christ that overcomes the powers of chaos and/or Evil, be it in the physical or spiritual sense.

INCARNATIONS OF EVIL

According to St Paul, demons seduce and tempt the believer constantly (1 Cor 7:5). ${ }^{16}$ This struggle, taking place in the mind of ordinary people and saints alike, can be depicted in various ways, especially in the case of saints fighting with the powers of Evil. ${ }^{17}$ In the case of desert hermits, for instance, texts relate about demons and devils that manifest

${ }^{15}$ Łaptaś 1999: 234-235.

${ }^{16}$ Nola 1987: 174.

${ }^{17}$ This kind of representations had also a kind of apotropaic function (Grotowski 2010: especially 74 and n. 53). 
themselves in a material or immaterial form and in iconography both kinds of appearances are depicted, often as gruesome monsters. When warrior saints are confronted with Evil, this usually takes place in an exclusively material and physical way, the saint struggling with his opponent in the form of a monster in animal or human shape.

The iconography of military saints often follows standard patterns and without explicit characteristics, attributes or epigraphy it is often difficult to distinguish one from the other. The kind of opponent that is depicted can help in identifying the saint, as in the case of St George, who is mostly shown on horseback, spearing a dragon, or St Mercurios, who is usually depicted killing John the Apostate. ${ }^{18}$

That does not mean that equestrian saints can always be identified with certainty on the basis of their victim. Often the artist has taken the liberty of coupling an 'incarnation of Evil' to a saint in a way that does not occur in hagiographical sources. Whereas the basis of such depictions in principle is a narrative, the image is also of a timeless, iconic character, one in which the message is that the martyr overcomes Evil by his virtue. In fact such representations show a reversal of roles: these military saints were martyrs, mostly killed during the persecutions of the third century, but their icons show them as winners of a fight, not as victims. ${ }^{19}$ An example of a problematic case, where identification on the basis of known hagiography is difficult, is a painting in the Upper Church of Banganarti (Room 21, Western wall). ${ }^{20}$ Here a standing military saint pierces a human figure that cannot be identified, while on the opposite side, to the left, another human figure stretches out his arms towards the saint. There is no doubt that the person being killed represents evil, while the other may be someone in distress, asking for help, but as a whole the identification remains a mystery and the tentative interpretation as St Menas by Bogdan Żurawski remains uncertain. ${ }^{21}$

The basis of this iconography is what we could call 'hero on horseback', a rather archetypical image that dates back to pre-Christian times. Roman emperors were portrayed on horseback and although the only equestrian statue that survives is that of Marcus Aurelius, there must have been many. ${ }^{22}$ In Egypt there was no tradition of a cavalry and pharaohs and gods were not depicted on horseback. The well-known sculpture from Faras, of Horus piercing a crocodile, now in the Louvre, is a typical amalgam of an Egyptian theme depicted in a Roman way. ${ }^{23}$ It can be considered a model for the Christian saints on horseback, which became extremely popular in the Nile valley. As in the case of the pre-Christian models, the saint on horseback is a prototype of Good defeating Evil and the various forms in which Evil is depicted in these scenes could be called incarnations. Most cases of representations of Evil in Nubian paintings are the ones depicted in connection with warrior

18 For the details of legends and iconography of warrior saints, see: Walter 2003.

19 Innemée 2019: 113-114.

20 Żurawski et al. 2014: 204-205.

21 Zurawski et al 2014: 204. A possible analogy that supports the identification of the saint can be the drawing in the Miracle of St Menas (British Museum OR.MS.6805); Bogdan Żurawski personal communication.

${ }^{22}$ The statue originally had a small figure of a defeated barbarian, now lost, under the raised foreleg of the horse, see: Stewart 2012: 264-277.

${ }^{23}$ For image and reference see website: Louvre: E 4850. 
saints. ${ }^{24}$ They can be in the guise of previously mentioned wild or monstrous animals, ${ }^{25}$ but Evil could also incarnate in the form of anthropomorphic demons or humans. Of the preserved paintings the majority can be identified on the basis of the accompanying inscription or the figure of the Evil incarnation overcome by the saint. ${ }^{26}$ These are images of the Saints Theodore Stratelates, Merkurios (the most numerous), Sisinios(?), George, Menas, Epimachos, and Phoibamon. Only in the case of the first four saints the figure of an Evil incarnation has been depicted or preserved.

\section{THE SNAKe}

Since the appearance of the snake in Genesis 3, the creature has been associated with Evil in the Jewish-Christian tradition. In hagiography and Nubian iconography it occurs in constellation with St Theodoros Stratelates. The original Theodoros was a recruit in the Roman army who was martyred for his faith, but in the later Coptic tradition he was made a general (stratelates) and a purely legendary story was added to his hagiography, about the town of Euchaita, where the local population worshipped a snake that demanded a young human victim annually. Theodoros slew the monster and delivered the town. ${ }^{27}$ The story combines the elements of the snake as an incarnation of Satan with the traditional attitude that pagan gods are identical with demons.

Depictions of St Theodoros as for now were found in the Paulos Cathedral in Faras, ${ }^{28}$ Petros Cathedral in Faras ${ }^{29}$ and in Old Dongola, where he was most probably painted in House $\mathrm{A}^{30}$ and the South-West Annex of the Monastery on Kom H. ${ }^{31}$ The snake is preserved in the examples from Paulos Cathedral (Fig. 2) and House A. In both cases the beast is depicted with a dark violet ridge and white abdomen. The form of a snake is the basis for an identification of a saint from House A as St Theodoros. ${ }^{32}$ Another fragment of a painting from Petros Cathedral in Faras shows a snake and a few details of a horse, so that this may also be a representation of St Theodoros. ${ }^{33}$ In this case a blue-grey body of the snake is covered in small scales.

${ }^{24}$ This overview has been made with a help of the study of warrior saints in Nubia by Tomasz Górecki (Górecki 1980), updated by Agnieszka Ryś in her unpublished Bachelor thesis (Ryś 2013).

${ }^{25}$ Although reptile monsters are usually used as symbolic depictions of Evil, this interpretation is not valid under all circumstances. In the representation of a cleric in the Room 11 of the Monastery on Kom $\mathrm{H}$ in Old Dongola (Martens-Czarnecka 2011: cat. no. 17), a crocodile-like creature has been presented under his feet. In this case it is most probably a reference to the events described in the Life of saint Pachomius, who used to travel on a crocodile across the Nile, see: Innemée 2016: 422-423.

${ }^{26}$ It is worth mentioning that the holy warriors were not always accompanied by evil figures. In two cases the figures refer to an idea of martyrdom, see: Innemée 2019.

27 O’Leary 1974: 262-264.

28 Jakobielski et al. 2017: 137-138, cat. no. 14.

29 Jakobielski et al. 2017: 327-329, cat. no. 103, although no figure of the snake is depicted.

30 Górecki 1980: n. 184; Martens-Czarnecka 2001: 255.

31 Martens-Czarnecka 2011: 210, cat. no. 114.

32 Górecki 1980: 249-252.

33 Jakobielski et al. 2017: 232, cat. no. 65. 


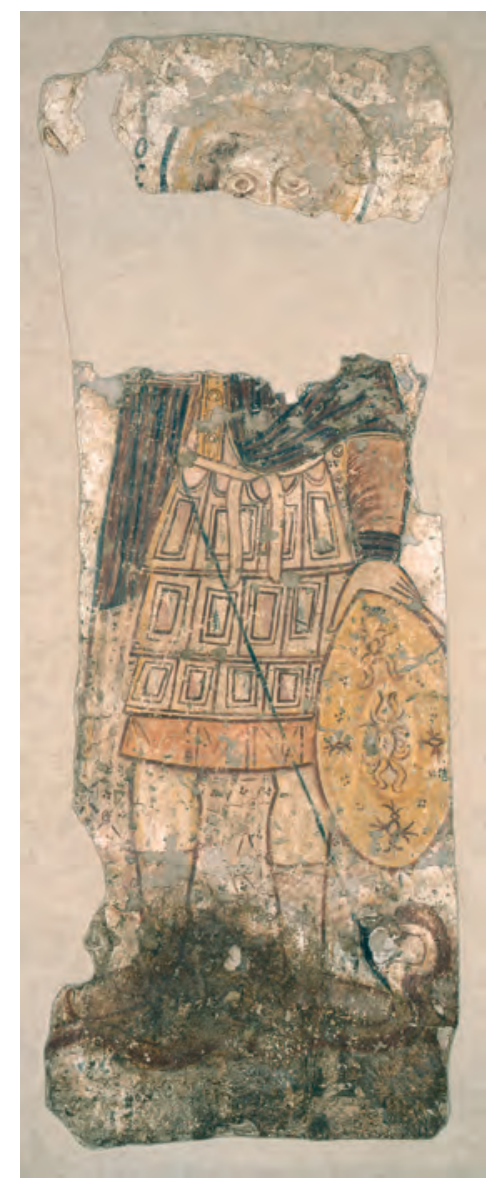

2. Theodoros Stratelates, Faras, the Cathedral of Paulos, inv. no. 234023 MNW (Phot. Z. Doliński/P. Ligier; courtesy of the National Museum in Warsaw).

As has been mentioned above, the snake is an animal closely associated with Evil, but depending upon the context and circumstances, its representation can be interpreted either as an image of Satan himself, a symbolic image referring to the forces of Evil, or as an agent of Satan, an actual physical presence, but not identical to Satan (see the chapter 'Hades' below). In the iconological analysis of images of snakes this should be carefully considered.

\section{Alabasdria(?)}

The gruesome story of St Sisinnios tells how his sister became possessed by a demon called Alabasdria, who made it a habit to drink the blood of young children. The saint consequently killed his sister in order to get rid of the demon. ${ }^{34}$ This female demon is

${ }^{34}$ O’Leary 1974: 258-259. 
3. Alabasdria, detail of a representation of St Sisinnos, Banganarti, Raphaelion (Phot. and digitally enhanced by W. Chmiel; courtesy of IKŚiO PAN).

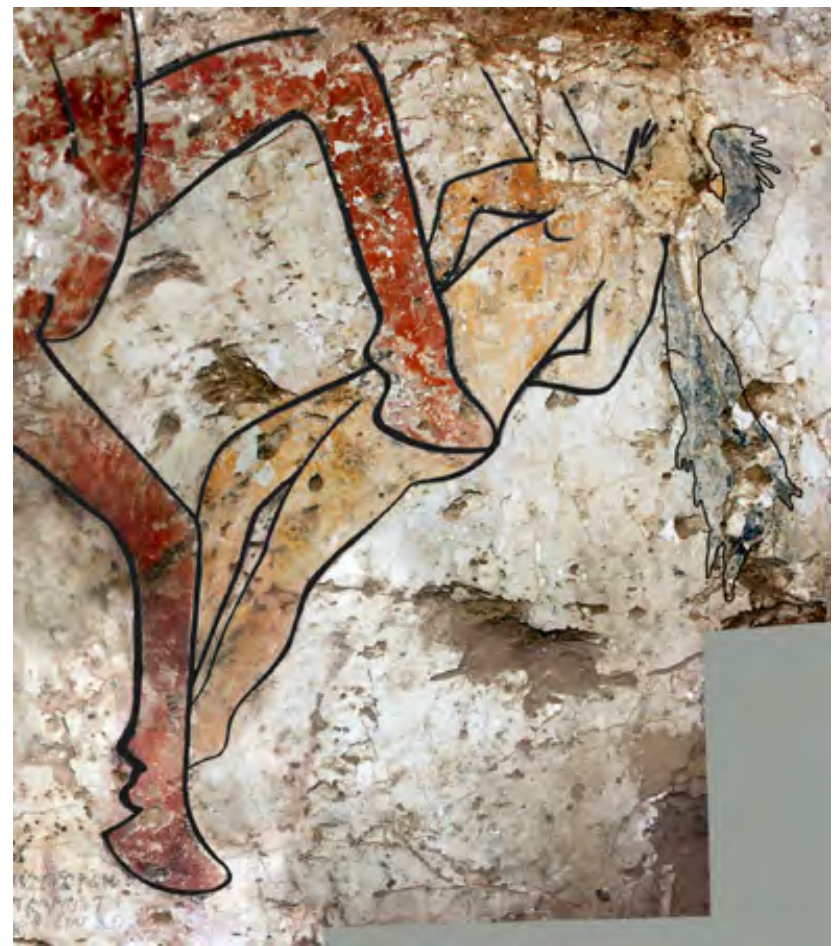

hypothetically identified in the painting in the Lower Church at Banganarti in the painting of a holy warrior, who is thus identified as St Sisinnios. ${ }^{35}$ The demon is represented as a naked woman with white complexion and long black hair (Fig. 3).

\section{Julian the Apostate}

Out of eleven paintings in Nubia identified so far as St Merkurios, in four cases the figure of a human adversary is preserved. This cannot be anyone but the emperor Julian the Apostate, a historical person, but at the same time considered by Christians as an incarnation of Evil. These are depictions from the Lower Church in Bagnanarti, ${ }^{36}$ the Central Church at Abdallah-n-Irqi, ${ }^{37}$ Abd el-Gadir, ${ }^{38}$ two depictions from Faras, Petros Cathedral, ${ }^{39}$ three depictions from Old Dongola, one in House $\mathrm{A},{ }^{40}$ one in the South-West Annex of the

\footnotetext{
35 Żurawski 2012: 301-309, cat. no. S8/S/1.

36 Żurawski 2012: 309-323.

37 Van Moorsel, Jacquet, Schneider 1975: 109-111.

38 Griffith 1926: 73, cat. no. 30.

39 Jakobielski et al. 2017: 324-326, 375-377, cat. nos 102, 122.

40 Górecki 1980: n. 212; Martens-Czarnecka 2001: 255.
} 
Monastery on Kom $\mathrm{H},{ }^{41}$ and a drawing in ink in the North-West Annex. ${ }^{42}$ Except for the painting in the South-West Annex, in all representation where the remains of the figure killed by the saint can be clearly seen it should most probably be identified as Julian the Apostate.

St Merkurios (third century) was not a contemporary of Julian the Apostate, but according to his hagiography, he had miraculously killed the emperor during a battle against the Persians, rising from the grave for one night. ${ }^{43}$ Only in three out of four of the above mentioned cases is it possible to distinguish details of the emperor's depiction. In all instances he is wearing a kind of royal costume. In the earlier example, from House A, Old Dongola, he is depicted en face, as a young man, with dark curly(?) hair and a kind of flat cylindrical diadem(?) decorated with a row of white dots (Fig. 4). He is wearing a white tunic and dark mantle tensed on his right shoulder. The later depictions from Banganarti and Faras show him as an older man with a black, long, pointed beard and moustache. In the scene from Banganarti he is dressed a similar way as in the previous example, while in the depiction from Faras he is wearing a white costume with long belted robe and trousers (Fig. 5). ${ }^{44}$

\section{ENEMIES}

A depiction of Evil, overcome by a holy warrior that is unique for Christian iconography, and dated to the twelfth century, was found on the wall of Chapel no. 21 of the Upper Church (Raphaelion) at Banganarti. There, an unidentified holy rider is holding a bunch of tied people on a thong (Fig. 6). ${ }^{45}$ A similar motif has been found in the Faras Cathedral of Petros as a part of an unidentified composition. ${ }^{46}$

It seems that this way of depicting was inspired by the Egyptian representations of the traditional enemies of the country, bound together or grabbed by their hair in a bunch by the king. As Bogdan Żurawski suggested, this motif was taken over in Meroitic art and such representations in temples may, in turn, have been the source of inspiration for Christian artists. ${ }^{47}$ If this is the case, a transformation has taken place in which a military/political opponent has been transformed into a personification of Evil. The hypothesis that such a representation has been adopted in Christian iconography from earlier tradition may be supported by the fact that one of the most popular terms used to define the Devil in Christian Nubia was the word $\dot{\varepsilon} \chi \theta \rho{ }^{\circ} \varsigma$ 'enemy’. ${ }^{48}$

41 Martens-Czarnecka 2011: 207-210, cat. no. 84.

42 Martens-Czarnecka 2011: 207, Fig. 105.

43 O’Leary 1974: 201-202.

44 Jakobielski et al. 2017: Fig. on p. 122.

45 Żurawski et al. 2014: 202, Fig. 10.

46 Jakobielski et al. 2017: 423-424, cat. no. 139.

47 Sackho-Autissier 2010: 182-185. A well-known examples in Meroitic art are for instance the relief of queen Amanitore and goddess Isis on the Apedemak temple of Naga (LD II, Pls 56, 57).

48 Such a term is used in two inscriptions from Banganarti, Upper Church (Łajtar forthcoming: cat. nos 24 and 964, however, in Old Nubian there is no such attestation (Vincent W.J. van Gerven Oei personal communication). 


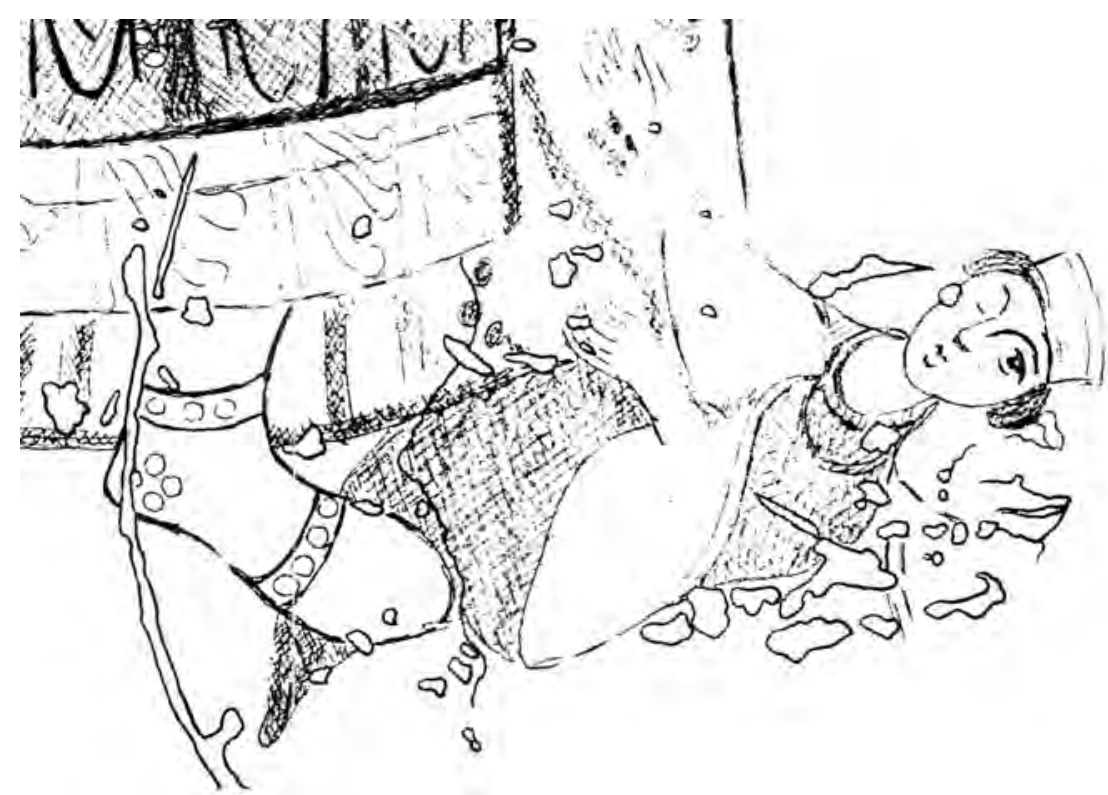

4. Julian the Apostate, detail of the representation of St Merkurios, Old Dongola, House A (Tracing: M. Steinborn; courtesy of IKŚiO PAN).

5. Julian the Apostate, detail of the representation of St Merkurios, Faras, the Cathedral of Petros (Phot. C. Calaforra-Rzepka, IR; courtesy of the National Museum in Warsaw).

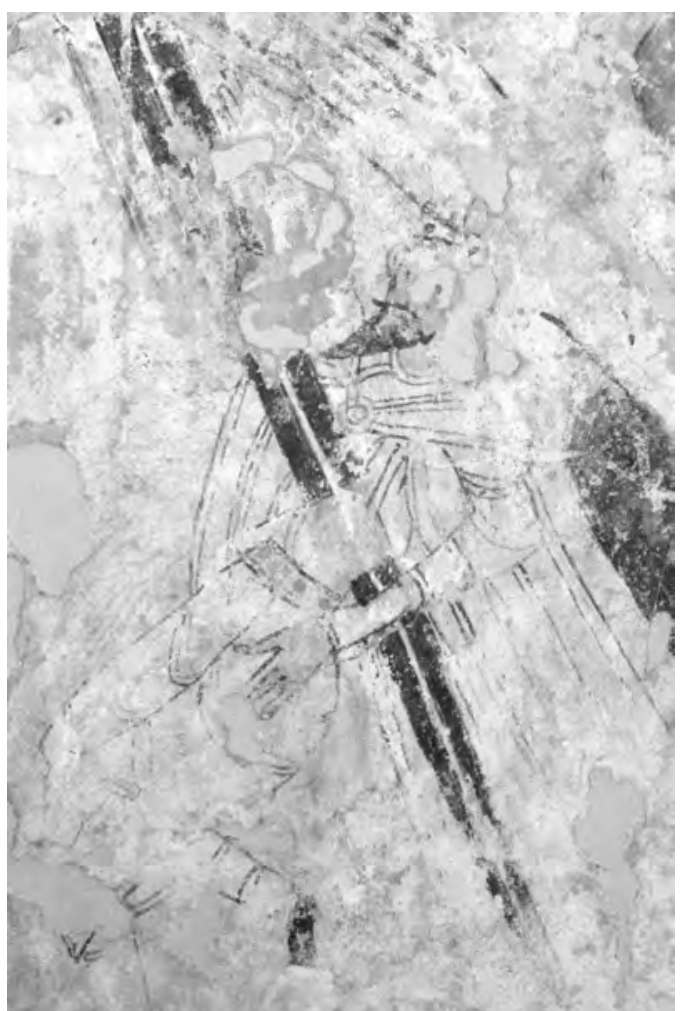




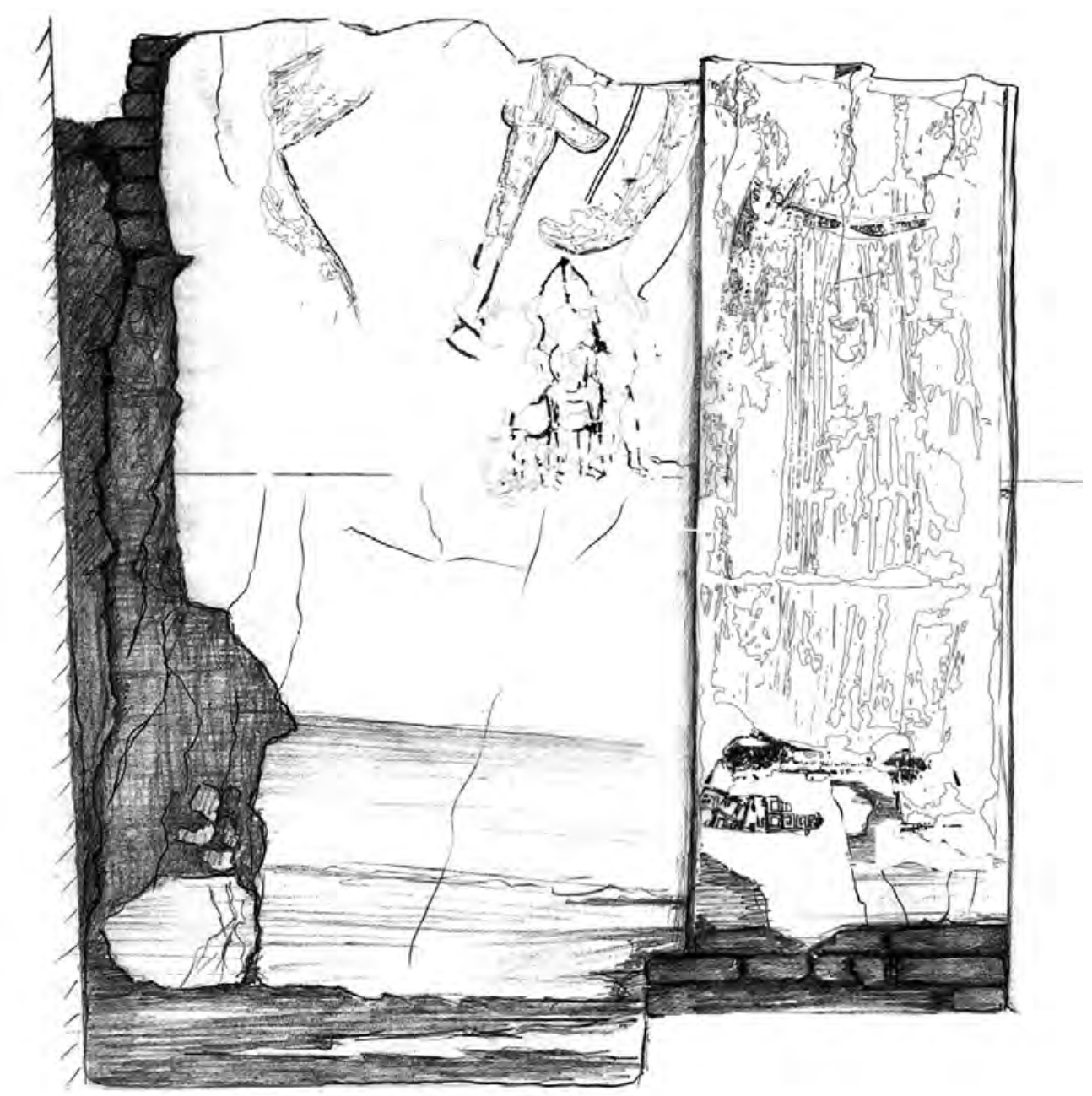

6. Enemies as evil powers, unidentified warrior saint, Banganarti, Raphaelion (Tracing: M. Momot; courtesy of IKŚiO PAN).

\section{THERIANTHROPIC IMAGES}

As mentioned before, biblical texts are not unequivocal concerning the appearance of the Devil or Satan. The idea of the fallen angel must have been the background of the winged creature, black instead of white and with wings of a bat rather those of a bird. Other zoomorphic elements can be added, such as horns and a tail. ${ }^{49}$

This most renowned way of representing the Devil, in an anthropomorphic form with some animal features, like wings, horns and tail (so-called therianthrophic) is a part of

49 For the idea of Jewish origins of such image of the Devil, see: Kulik 2013. 
a representation of St George on horseback on the north wall of the northern aisle of the church in Abd el-Gadir dated to the thirteenth century (Figs 7-8). ${ }^{50}$ This is surprising, since St George is usually depicted in combat with a dragon.

The other example of such a winged depiction of evil power comes from Room 3 of the South-West Annexe of the Monastery on Kom H in Old Dongola. It represents the Archangel Raphael in a scene of a fight with a demon, a figure lying on his back (Fig. 9). The bad state of preservation makes it difficult to come to a final identification of this figure. At first it was suggested that it was a rhinoceros or single horned animal, ${ }^{51}$ but in this case it concerns a two-horned beast and could be the demon Asmodeus, mentioned in Tobit 3:8 as the evil spirit who killed all the future spouses of Sara before the wedding night. ${ }^{52}$ Recent documentation of the painting shows that it is more likely that he has wings, instead of horns. Rafael, appearing incognito to Tobit, helps him to break the spell. In the story of Tobit there is no physical fight between the Archangel and the demon and if this painting does indeed depict Asmodeus, it is rather an allegorical than a narrative image of the struggle between Good and Evil.53

\section{THE DEVIL's HUMAN HELPERS}

Not only demons but also people possessed by satanic power can be portrayed as the Devil's helpers. Such figures occur in Christian iconography and this is the case in Nubian painting as well. In two scenes, one from the Old another from the New Testament, such diabolic human characters are depicted.

The first one is the Old Testament scene based on Daniel 3, a representation of the Three Youths in the Fiery Furnace, a subject that has become an almost obligatory element of the iconographic programme of Nubian churches. ${ }^{54}$ The scene gives a central place to the angel, who is generally depicted as the Archangel Michael in his role as a protector of mankind. ${ }^{55}$

In one example of this theme, located on the west wall of Room 23 in the North-West Annex in the monastery in Old Dongola, this scene is enriched by the figures of the stokers that are adding firewood to the furnace (Fig. 10). Such a detail occurs sometimes on Early Christian sarcophagi and refers to the description in the Book of Daniel (Dan 3:46). Indeed it seems that the fire of the furnace is considered a parallel to the fires of Hell and the stokers in that case figure here as a kind of devils..$^{56}$

Evil powers were trying to disturb God's plan and appear in scenes from the New Testament in Nubian art in two cases. Both times they appear as Roman soldiers, first

50 Griffith 1928: 75; cat. no. 41; for dating, see also: Godlewski 1995: 52.

51 Martens-Czarnecka 2011: 197, cat. no. 93.

52 Łaptaś 2016: 467-469.

53 It is worth to note that demon Asmodeus is mentioned in one of the inscriptions from the Upper Church in Banganarti (Łajtar forthcoming: cat. no. 359), as well as in the Faras Cathedral (Łajtar 2009: 111-115).

54 Zielińska 2010: 649, Fig. 7.

55 Łaptaś 2019: 105.

56 Martens-Czarnecka 2011: 128, cat. no. 49. 


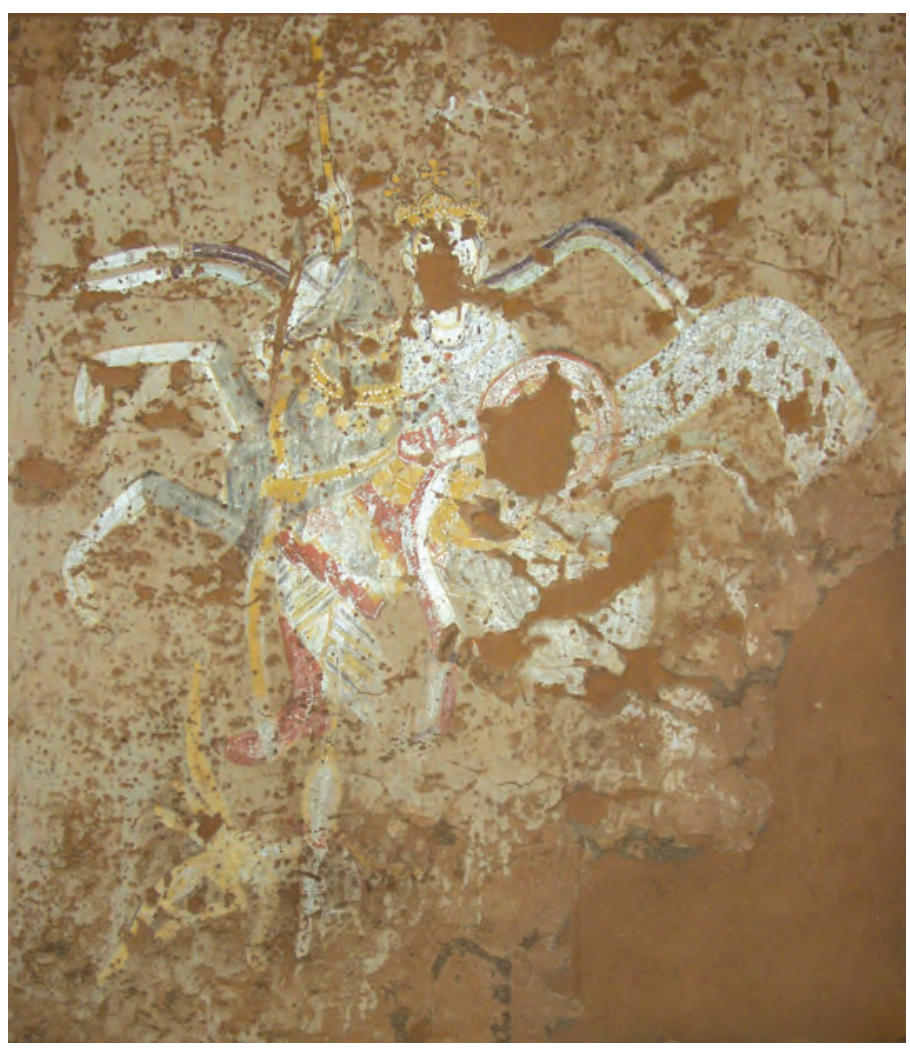

7. St Georgios fighting a Devil, Abd el-Gadir, inv. no. KH.24313 (Phot. D. Zielińska; courtesy of the Sudan National Museum).

8. St Georgios, detail of the Devil (Digitally enhanced by D. Zielińska).

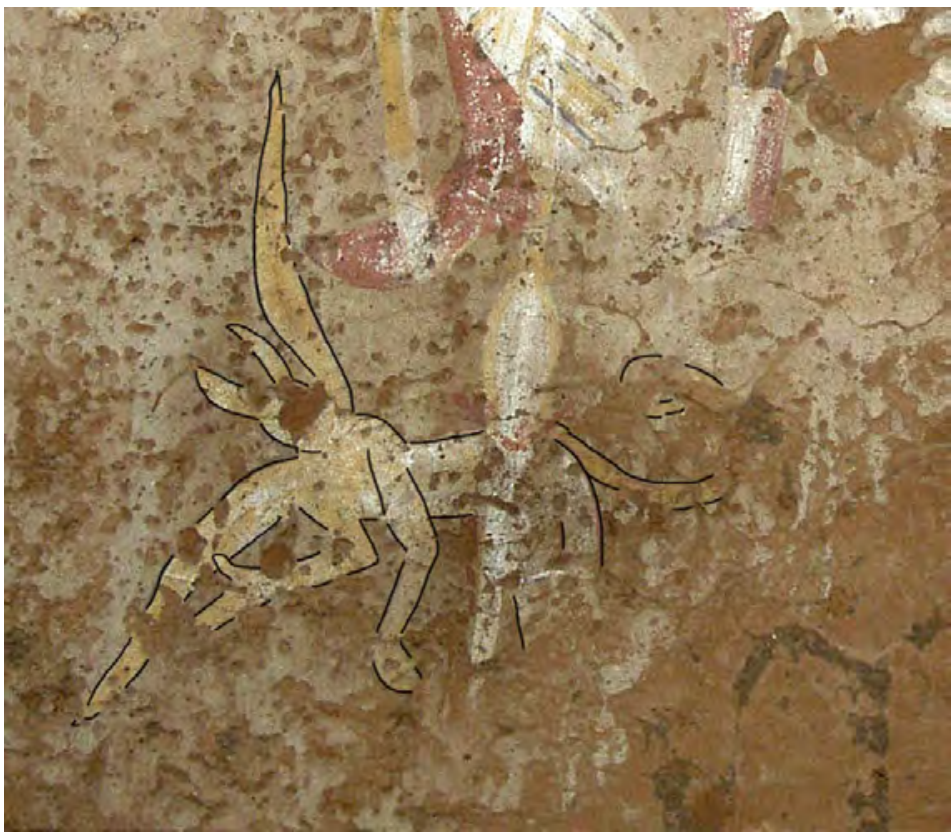


9. Archangel Raphael fighting with Asmodeus(?), Room 3 of the South-West Annex of the Monastery on Kom H in Old Dongola (Digitally enhanced by D. Zielińska; based on: Martens-Czarnecka 2011: cat. no. 93).

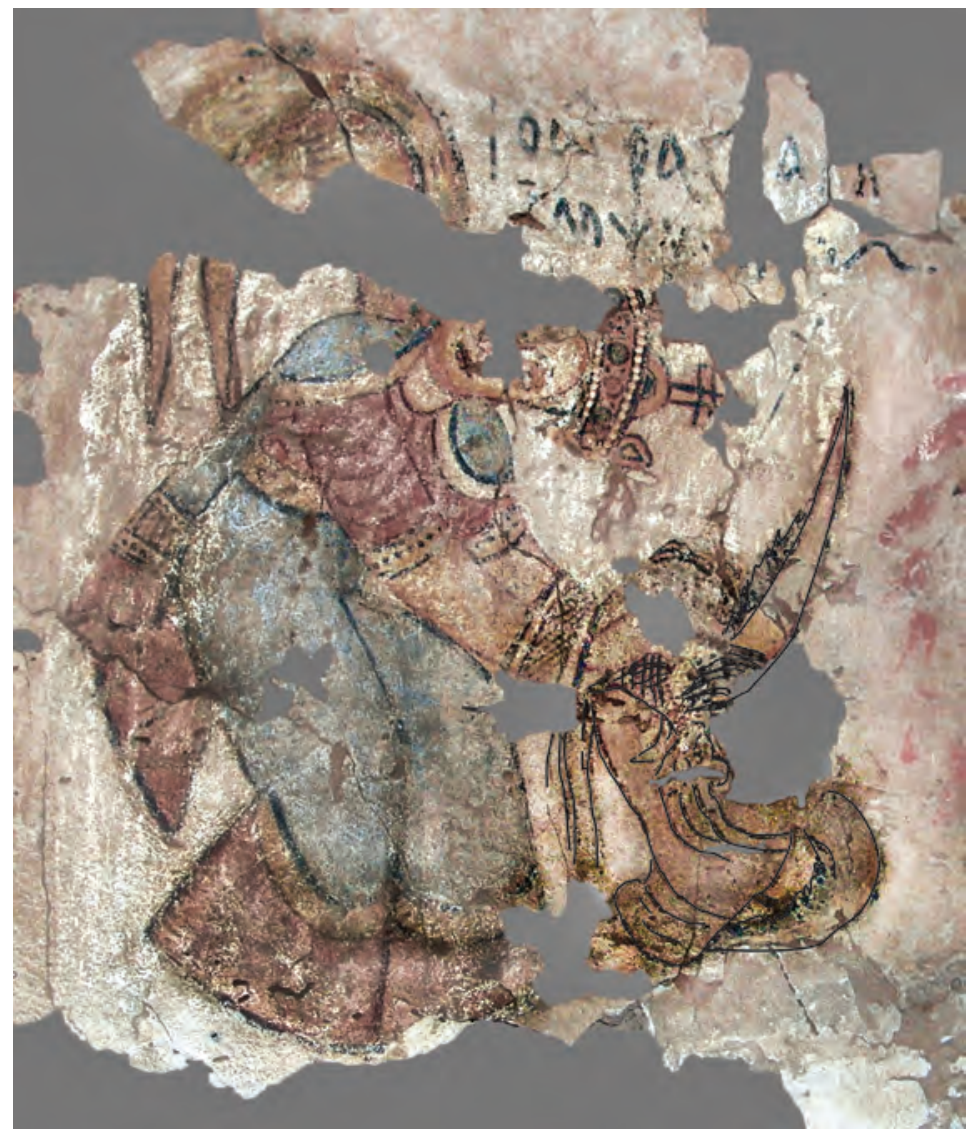

sent by Herod to find the newborn King of the Jews (Math 2:16) and then in the scene of Deposition from the cross.

The Massacre of the Innocents, in two different varieties, occurs only in the Annexes of the Monastery on Kom H in Old Dongola. In both cases it can be concluded from the presence of figures of Roman soldiers in Nativity scenes that it concerns this subject. ${ }^{57}$ Soldiers holding swords are visible in the vicinity of a crib, running in opposite directions. In the first example they are wearing short tunics, while in the second their costume seems to reflect oriental patterns and contains also puffy trousers. ${ }^{58}$

${ }^{57}$ Martens-Czarnecka 2011: 141-143, cat. nos 41, 107, 136a. Although at least two of these examples, showing soldiers by the manger, were interpreted by Magdalena Łaptaś as a reference to mythological story of the birth of Zeus (IX International Coptological Congress, Cairo 2008; presentation: Two Dancing Warriors in the Nativity Scene from Old Dongola: An Attempt of the Iconographical Interpretation).

58 For more details about military costume in Nubian wall-painting, on the basis of the iconography of the holy warriors, see: Górecki 1980: 196-215. 


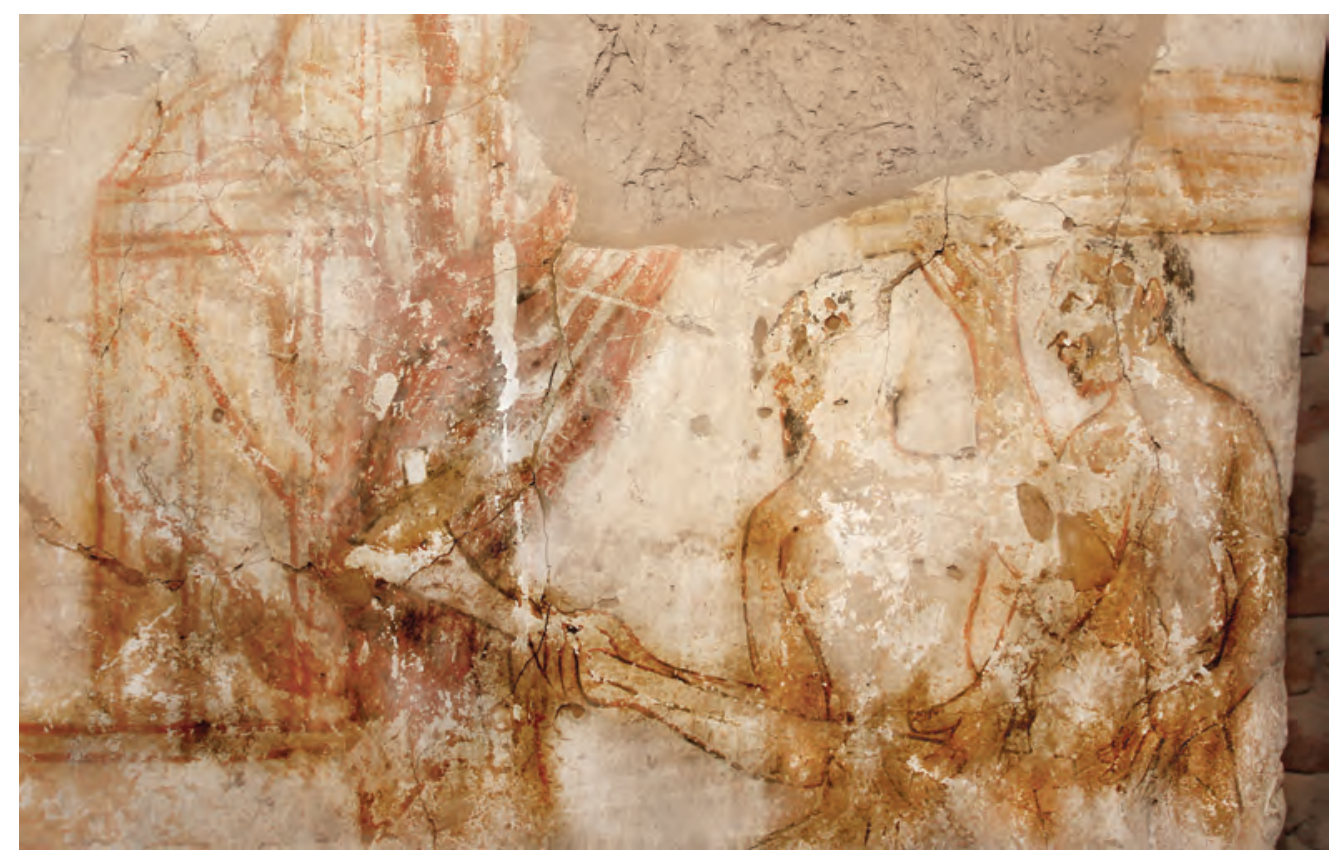

10. Three Youths in the Fiery Furnace, detail of the stokers, Room 23 of the North-West Annex in the Monastery on Kom H in Old Dongola (Phot. D. Zielińska; courtesy of PCMA).

The scene of the Massacre of the Innocents occurs only once as an independent representation, in the South-West Annex, Room 6, in Old Dongola. Its very bad state of preservation makes it difficult to distinguish all the details. It seems that figures have no characteristic elements of military costumes and only big swords can refer to their profession (Fig. 11). ${ }^{59}$

Roman soldiers occur again in the scene of Crucifixion known from Faras Cathedral. ${ }^{60}$ Two of them are guarding the Deposition, while the third one is pulling out a nail from Christ's hand. All are wearing a kind of stylised, Nubian version of military uniforms, that consist of long tunics(?) covered with an ornament of diagonal net and bended with narrow belts, long with trousers and domed headdresses topped with round elements (Fig. 12).

The characteristic that these figures have in common, typifying them as agents of Evil, is the fact that they are depicted in profile rather than frontal, with large noses. Apart from depictions in the scenes discussed above there is an individual representation of a rather small size (as used in multi-figurative narrative scenes) that could be a 'portrait study' of such a bad character. ${ }^{61}$

\footnotetext{
59 Martens-Czarnecka 2011: 145, cat. no. 114.

60 Jakobielski et al. 2017: 295-299, cat. no. 90.

${ }_{61}$ Martens-Czarnecka 2011: 259, cat. no. 47.
} 


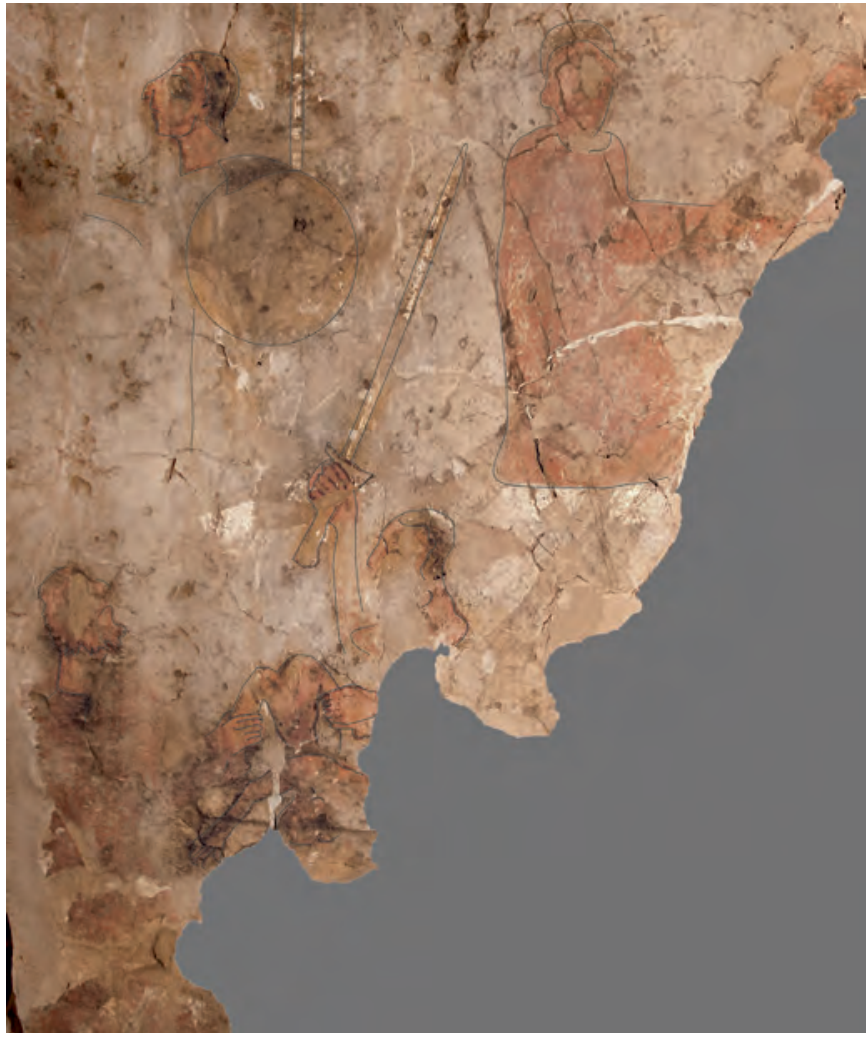

11. Massacre of the Innocents, Room 6 of the South-West Annex in the Monastery on Kom $\mathrm{H}$ in Old Dongola (Phot. and digitally enhanced by D. Zielińska; courtesy of PCMA).
12. Passion cycle, detail of representations of soldiers, Faras, the Cathedral of Petros, inv. no. KH.24335 (Phot. D. Zielińska; courtesy of the Sudan National Museum).

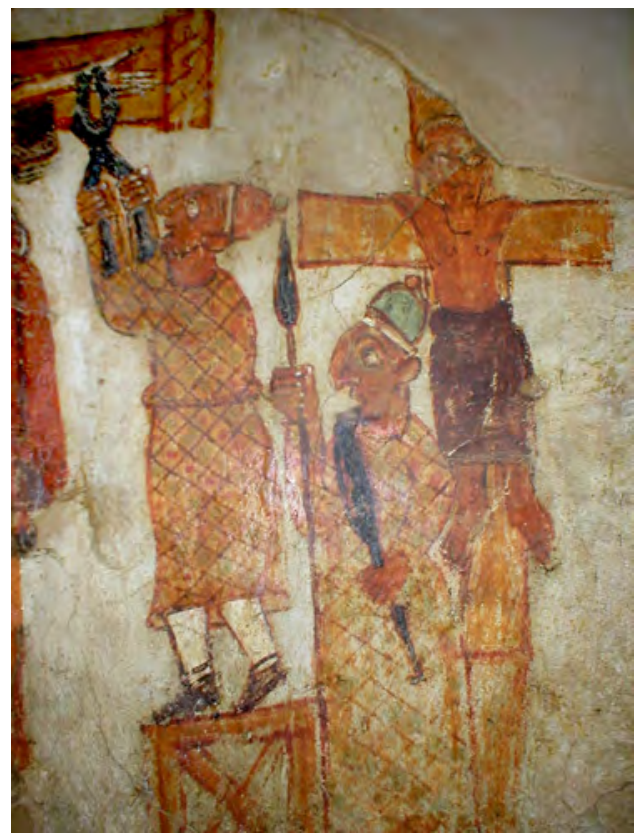


HADES

The descent of Christ into the netherworld in order to deliver the souls of the just is an episode from the Passion of Christ that has become an important subject in eastern Christianity and part of the cycle of twelve main feasts (dodekaorton) as depicted in Byzantine church interiors. Although it is commonly referred to as Anastasis (Resurrection), the real subject is the descent of Christ into Hades, since the moment of the Resurrection itself is not allowed to be depicted according to Byzantine tradition. ${ }^{62}$ Since the canonical gospels are silent about what happened between the burial of Christ and the Resurrection, the need must have been felt to fill this lacuna. The apocryphal Gospel of Nicodemus contains an appendix (also known as the Descensus ad Infernos) in which the descent of Christ into the netherworld is described, relating how he delivers the souls of the just (dikaioi) of the Old Covenant, ranging from Adam to John the Baptist. ${ }^{63}$ This apocryphon must have been influential enough to have the descent of Christ mentioned in the Apostles' Creed. ${ }^{64}$ Although in some editions this is translated as '...he descended into hell ...', the Greek text

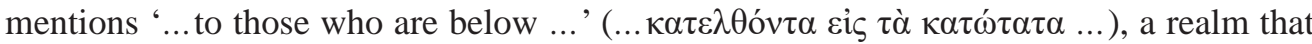
is neither Heaven nor Hell, but the place that is referred to in the Old Testament as Sheol (for instance Isaiah 38:18). ${ }^{65}$ This term is translated in the Septuagint as Hades. Hades originally was the god of the dead in Greek mythology, and as such also a personification of the hereafter, a gloomy realm in ancient Greek belief that was called with the same name. In the Christian tradition this Hades as a character was transformed into a servant of Satan, in accordance with an Old Testament attitude that the gods of the 'pagans' were in fact demons. In the Gospel of Nicodemus the main dramatis personae are Christ, Satan and Hades, the latter one being the guardian of the netherworld where the souls are being kept imprisoned. Christ first asks for access to the netherworld and when Satan and Hades refuse to open the gates, Christ breaks them with force and delivers the souls of the just. It should be remembered that Hades as a realm was not identical to Hell, but the place where all souls were lodged after death, in order to await the Last Judgement, expected to take place after the Parousia. Tertullian in his De Anima and the Discourse to the Greeks concerning Hades by Hippolytus of Rome are quite clear about this matter. ${ }^{66}$

In monumental Byzantine art the Anastasis only occurs in post-iconoclastic art and probably the earliest representation is found on the Fieschi Morgan reliquary (early ninth

62 The post-iconoclastic tradition allows only the depiction of what has been seen by human eyes, and the moment of the Resurrection was not considered as one of these events, Ouspensky 1978: 183.

63 Hennecke, Schneemelcher 1968: 35-53. The Gospel of Nicodemus was probably written in the second century, a period when Christian ideas about Hell had apparently not yet been formulated clearly and the antique concept of the underworld (Hades) was adopted into ideas about the hereafter (Ainalis 2018: 273-274).

${ }^{64}$ In Ephesians 4: 9 an allusion to the descent of Christ is given: Now that he ascended, what is it but that he also descended first into the lower parts of the earth?

65 In literature the distinction between Hades and Hell is still (incorrectly) not always made, as for instance in: Maguire 2018: 304.

${ }_{66}$ De Anima 58; Waszink 1933: 193-197; see also website: Discourse concerning Hades. On this matter, see also: Hill 1989. 
century(?)), ${ }^{67}$ where Christ is represented trampling on a figure that represents Hades. In most of the later representations the figure of Hades is absent, and only the gates of Hades (as a realm) are depicted, often accompanied by a large quantity of smashed locks, bolts and hinges. This could be explained by the argument (apparently used, especially by iconoclasts) that in the case of cult images the worshipper was also forced to prostrate himself in front of a representation of a servant of Satan. ${ }^{68}$

Two examples of the Descent into Limbo are known from Nubian painting and in both cases Hades is represented under the feet of Christ and both can be dated to the tenth/eleventh century. In the one that was found in the Lower Church of Banganarti, Christ is depicted trampling on the outstretched figure of Hades, while he grabs Adam by the hand. ${ }^{69}$ The image represents victory over death, personified by Hades, which should be distinguished from victory over Satan. Although in the Gospel of Nicodemus Satan is kept in chains after the liberation of the just, the final battle between the forces of Good and Evil is still to come, as is the Final Judgment and admitting the righteous to heaven and sending the damned to Hell. ${ }^{70}$

Such a clear distinction between victory over death and Satan occurs in a slightly later painting, one of the aforementioned scenes of the Passion cycle from Faras (Fig. 13). ${ }^{71}$ In the lower left corner of what must have been an elaborate sequence of Passion scenes, Christ is shown, standing on the back of a black, prostrate figure, while stretching out his arms to the naked figures of Adam and Eve. Behind him there is a snake that seems to encircle five human heads. Although Stefan Jakobielski and others identity the black figure as Satan, he should be Hades, as is usual in the Anastasis composition. The snake, an unusual element, is most likely to be identified as Satan, escaping his fate till the Day of Final Judgment. ${ }^{72}$ In the context of this scene the snake refers to Satan as he appeared in the Book of Genesis. The fact that both Hades and Satan are depicted here can be seen as an indication that the painter was well aware of the iconographical implications and the difference between Hades and Satan.

In the Greek Euchologion Mega, the collection of prayers for liturgy and other sacraments, dating back in its origins to the sixth century, there is a prayer for the dead that has been taken over in Nubia. Not only was this prayer said during funerals, but extracts of it occur in numerous funerary stelae. Approximately one hundred of these are known from

67 Metropolitan Museum of Art, New York: website Metmuseum: accession no. 17.190.715a, b; Kartsonis 1986: 94-125, Fig. 24g.

68 Maguire 2018: 312. A rare example of the personification of Hades in monumental art is the mosaic of Nea Moni (eleventh century), where he is depicted in full length under the feet of Christ (Kartsonis 1986: Fig. 85).

${ }^{69}$ Żurawski 2012: 241-290. Bogdan Żurawski also sees in the motif of trampled person an indigenous Kushite tradition (Żurawski 2012: 288). The use of mythological motifs in Nubian iconography, especially Hades in Anastasis scenes has been also discussed by Magdalena Łaptaś (XXII International Congress of Byzantine Studies, 2011; presentation: Mythological Motifs in Nubian Art).

70 Żurawski 2012: 245, 250.

71 Jakobielski et al. 2017: 295-300, cat. no. 90.

72 This interpretation was also given by Vantini 1990: 658. 


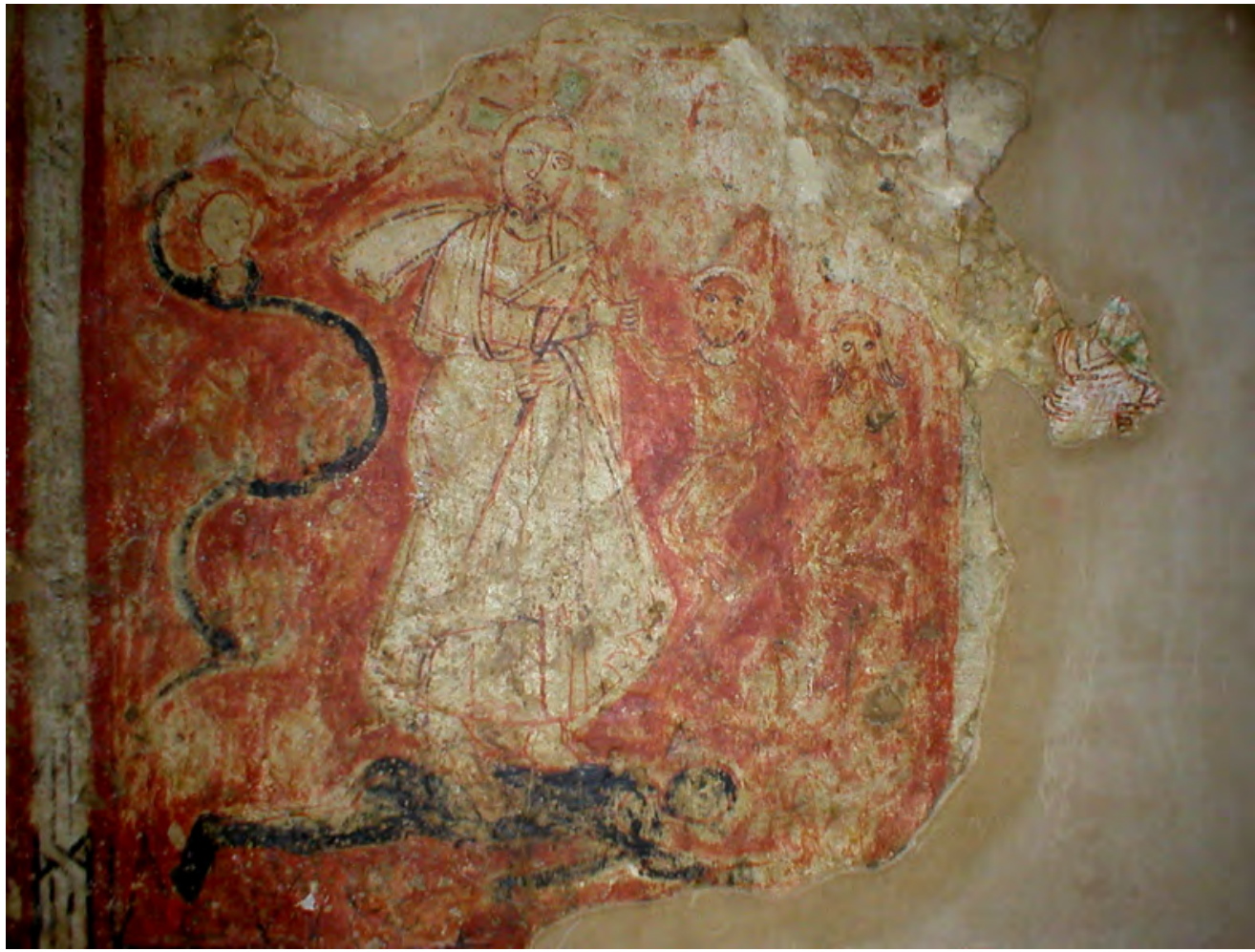

13. Passion cycle, detail of representations of Hades and Satan (snake), Faras, the Cathedral of Petros, inv. no. KH.24335 (Phot. D. Zielińska; courtesy of the Sudan National Museum).

Nubia. The opening sentence, occurring with slight variations, reads: God of the spirits and of all flesh, you who defeated death and trodden down Hades and given life to the world ... It is remarkable that in the original Greek Orthodox version the formulation 'and trodden down the devil ( $\delta$ ó $\beta$ o $\lambda o v)$ ' is used, while the Nubian versions use the term Hades

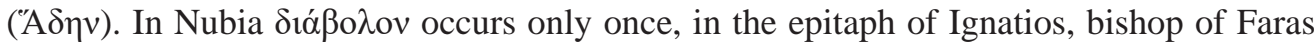
(died AD 802). ${ }^{73}$ It probably shows that also here one was very well aware of the difference between the Hades and the Devil (Satan) and that the 'correction' of the euchologion-text in the Nubian version was a conscious and deliberate one.

\section{CONCLUSIONS}

Evil, its representatives and personifications in the context of the Christian tradition, is a pluriform and complicated matter in which New Testament attitudes seem to be a continuation of mainly Old Testament traditions, with an influence from the Jewish apocryphal tradition. This pluriformity is reflected in the Christian iconography of Nubia as well.

${ }^{73}$ Łajtar 1996; 2003: XXI-XXII. The authors wish to thank Adam Łajtar for his remarks on this topic. 
Satan and his deputies (demons) can be depicted in anthropomorphic and theriomorphic form, as well as hybrids of these. Sources of inspiration for these depictions show a fusion of biblical and Late Antique elements, that were common tradition of the contemporary Christian world. Nevertheless it can be observed that Nubian artist could be creative in this topic. The fact that an established iconographical type of St George killing a dragon has been changed by replacing the personification of the Evil by a therianthrophic imagery can suggest that they were treating this personification as a symbolic representation of the Evil and not the reference to the life of St George. An even more creative phenomenon was the use of an element that Nubian artists derived from their own tradition. The motif of tonged enemies as personification of evil powers occurred at some point in eleventh/twelth century. This kind of a 'Meroitic renaissance' is visible in some other iconographical details, like 'elevation gesture' but also Nubian royal regalia. ${ }^{74}$

A number of mural paintings show various narrative and iconic themes in which the confrontation between the forces of Good and Evil are represented. Satan and his helpers can be considered enemies of mankind and/or of God. In the case of depictions of the struggle between saints (often military saints) and Satan, the scenes represent both a hagiographic narrative as well as a more timeless image of the struggle between Good and Evil, life and death. In this context the Nubian indigenous idea of representing such powers using iconographic motifs known from the Kushite period and expressing it also in language seems to be an original Nubian addition to this repertoire. The central theological message of Christianity is that life is regained by the death of Christ, a theme depicted in Anastasis representations. The warrior saints, depicted as defeating an incarnation of Evil, are in fact martyrs, who lost their lives. This may be the central paradox in the ideological message behind depictions of Evil: the one who fights Evil seemingly loses his life, but wins the battle.

\section{References}

Ainalis, Z.D. 2018: From Hades to Hell, Christian Visions of the Underworld (2nd-5th centuries CE), [in:] Ekroth, G., Nilsson, I. (Eds), Round Trip to Hades in the Eastern Mediterranean Tradition: Visits to the Underworld from Antiquity to Byzantium, Leiden-Boston, 271-286

Borgeaud, P. 2010: 'Silent Entrails': The Devil, His Demons, and Christian Theories Regarding Ancient Religions, HistRel 50/1, 80-95

Brenk, B. 1990: Teufel, [in:] Kirschbaum, E. (Ed.), Lexikon der christlichen Ikonographie 4, Rome-Freiburg-Basel-Vienna, 295-300

Clédat, J. 1904: Le monastère et la nécropole de Baouit, MIFAO 12, Cairo

Discourse concerning Hades: https://en.wikisource.org/wiki/Discourse_to_the_Greeks_ concerning_Hades (accessed January 10, 2019)

${ }^{74}$ For the idea of the origin of some element of royal costume in Meroitic tradition, see: Woźniak 2013; 2016; as for the regalia, compare: Żurawski 1999, but also Godlewski 2008: 273. 
Godlewski, W. 1982: Some Comments on the Wall Painting of Christ from Old Dongola, [in:] Plumley, J.M. (Ed.), Nubian Studies, Proceedings of the Symposium for Nubian Studies, Sellwyn College, Cambridge 1978, Warminster, 95-99

Godlewski, W. 1995: The Late Period in Nubian Art - from the Middle of $13^{\text {th }}$ to the End of $14^{\text {th }}$ Centuries, [in:] Gundlach, R., Kropp, M., Leibundgut, A. (Eds), Sudan Past and Present / Der Sudan in Vergangenheit und Gegenwart, NordostafrikanischWestasiatische Studien 1, Frankfurt a/Main, 37-63

Godlewski, W. 2008: Bishops and Kings. The Official Program of the Pachoras (Faras) Cathedrals, [in:] Between the Cataracts. Proceedings of the $11^{\text {th }}$ Conference for Nubian Studies, Warsaw University, 27 August - 2 September 2006, Part One, Main Papers, PAM Supplement Series 2.1, Warsaw, 263-282

Godlewski, W. 2013. Dongola - ancient Tungul. Archaeological guide, PCMA Archaeological Guides 1, Warsaw

Górecki, T. 1980: Z problematyki ikonografii świętych wojowników w malarstwie ściennym katedry w Faras, RMNW 24, 173-259

Griffith, F.Ll. 1928: Oxford Excavations in Nubia: The Church of Abd el-Qadir near Second Cataract, AAALiv 15, 63-82

Grotowski, P. 2010: Arms and Armour of the Warrior Saints. Tradition and Innovation in Byzantine Iconography (843-1261), The Medieval Mediterranean 87, Leiden

Hennecke, E., Schneemelcher, W. 1968: Neutestamentliche Apokryphen I, Evangelien, Tübingen

Hill, C.E. 1989: Hades of Hippolytus or Tartarus of Tertullian? The Authorship of the Fragment De Universo, VigChr 43/2, 105-126

Innemée, K.C. 2015: The Doors of Deir a-Surian Commissioned by Moses of Nisibis: Some Observations on the Occasion of their Restoration, [in:] Doerfler, M., Fiano, E., Smith, K. (Eds), Syriac Encounters, Papers from the Sixth North American Syriac Symposium, Duke University, 26-29 June 2011, Early Christian Studies 20, Leuven, 193-214

Innemée, K.C. 2016: Monks and bishops in Old Dongola, and what their costumes can tell us, [in:] Łajtar, A., Obłuski, A., Zych, I. (Eds), Aegyptus et Nubia Christiana. The Włodzimierz Godlewski Jubilee Volume on the Occasion of his 70th Birthday, Warsaw, 411-434

Innemée, K.C. 2019: A Man in a Vessel, Once More, EtudTrav XXXII, 111-120

Jakobielski, S. 1979: Dongola 1976, EtudTrav XI, 229-244

Jakobielski, S., Martens-Czarnecka, M., Łaptaś, M., Mierzejewska, B., Rostkowska, B. 2017: Pachoras, Faras: The Wall Paintings from the Cathedrals of Aetios, Paulos and Petros, PAM Monograph Series 4, Warsaw

Jewish Encyclopedia: http://www.jewishencyclopedia.com (accessed January 10, 2019)

Kartsonis, A.D. 1986: Anastasis, the Making of an Image, Princeton

Kulik, A. 2013: How the Devil Got His Hooves and Horns: The Origin of the Motif and the Implied Demonology of ' 3 Baruch', Numen 60/2-3, 195-229

Louvre: https://www.louvre.fr/en/recherche-globale (accessed Janury 10, 2019) 
Łajtar, A. 1996: Varia Nubica IV: Das älteste nubische Epitaph mit dem Gebet vom sogenannten Typus Euchologion Mega?, ZPE 113, 101-108

Łajtar, A. 2003: Catalogue of the Greek Inscriptions in the National Museum at Khartoum (I. Khartoum Greek), OLA 122, Leuven-Paris-Dudley MA

Łajtar, A. 2009: Varia Nubica XII-XIX, JJP XXXIX, 83-119

Łajtar, A. forthcoming: The Late Christian Pilgrimage Centre at Bagnanarti. The Evidence of Inscriptions, JJP-Suppl., Warsaw

Łaptaś, M. 1999: Comments on Wall Paintings from House A in Old Dongola, [in:] Emmel, S., Krause, M. (Eds), Ägypten und Nubien in späntikier und christlicher Zeit. Akten des 6. Internationalen Koptologenkongresses, Münster, 20.-26. Juli 1996, vol. I, SKCO 6, Wiesbaden, 230-237

Łaptaś, M. 2016: Archangel Raphael as protector, demon tamer, guide and healer. Some aspects of the Archangel's activities in Nubian painting, [in:] Łajtar, A., Obłuski, A., Zych, I. (Eds), Aegyptus et Nubia Christiana. The Włodzimierz Godlewski Jubilee Volume on the Occasion of his 70th Birthday, Warsaw, 411-434

Łaptaś, M. 2019: The Position of the Archangel Michael within the Celestial Hierarchy: Some Aspects of the Manifestation of his Cult in Nubian Painting, [in:] Gilhus, I.S., Tsakos, A., Wright, M.C. (Eds), The Archangel Michael in Africa: History, Cult, and Persona, London, 95-108

Maguire, H. 2018: Why did Hades become beautiful in Byzantine Art?, [in:] Ekroth, G., Nilsson, I. (Eds), Round trip to Hades in the Eastern Mediterranean Tradition: Visits to the Underworld from Antiquity to Byzantium, Cultural Interactions in the Mediterranean 2, Leiden-Boston, 304-321

Mango, C. 1992: Diabolus Byzantinus, [in:] Homo Byzantinus, Papers in Honor of Alexander Kazhdan, DOP 46, Washington DC, 215-223

Martens-Czarnecka, M. 2001: Wall Paintings Discovered in Old Dongola, [in:] Jakobielski, S., Scholz, P.O. (Eds), Dongola-Studien. 35 Jahre polnischer Forschungen im Zentrum des makuritischen Reiches, Bibliotheca nubica et aethiopica 7, Warsaw-Wiesbaden, 253-284

Martens-Czarnecka, M. 2011: The Wall Paintings from the Monastery on Kom $\mathrm{H}$ in Dongola, Dongola 3, Nubia III, Warsaw

Mauskopf Deliyannis, D. 2014: Ravenna in Late Antiquity, Cambridge

McMahon, A. 2009: The Lion, the King and the Cage: Late Chalcolithic Iconography and Ideology in Northern Mesopotamia, Iraq 71, 115-124

Metmuseum: https://www.metmuseum.org (accessed October 23, 2019)

Moorsel, P. van, Jacquet, J., Schneider, H. 1975: The Central Church at Abdallah Nirqi, The Netherlands excavations in Nubia, Abu Simbel North 1962-1964, Leiden

Morgan, L. 1995: Of Animals and Men: the Symbolic Parallel, [in:] Morris, Ch. (Ed.), Klados: Essays in Honour of J.N. Coldstream, BICS Supplement 63, London, 171-184

Nola, A.M. di 1987: Il diavolo. Le forme, la storia, le vicende di Satana e la sua universale e malefica presenza presso tutti i popoli, dall’antichità ai nostri giorni, Roma 
O’Leary, L. de 1974: The Saints of Egypt in the Coptic Calendar, Amsterdam Ouspensky, L. 1978: Theology of the Icon, Crestwood NY

Ravenna: http://03varvara.wordpress.com/2011/08/25/unknown-artist-christ-the-warriorsacellum-archiepiscopale-archiepiscopal-chapel-ravenna-italy-6th-century/ (accessed January 10, 2019)

Ryś, A. 2013: Przedstawienia świętych wojowników w malarstwie nubijskim, unpublished BA thesis, University of Warsaw, Warsaw

Sackho-Autissier, A. 2010: Le thème de l'ennemi vaincu dans l'art méroitique, [in:] Baud, M. (Ed.), Méroé, un empire sur le Nil, Paris, 182-185

Schnackenburg, R., Rahner, K. 1986: Teufel, [in:] Lexikon für Theologie und Kirche 10, Freiburg, 2-4

Stewart, P. 2012: The Equestrian Statue of Marcus Aurelius, [in:] Ackeren, M. van (Ed.), A Companion to Marcus Aurelius, Blackwell Companions to the Ancient World 186, Hoboken NJ, 264-277

Vantini, G. 1990: The Faras ‘Golgotha’ and the Apocrypha, [in:] Scholz, P.O., Müller, C.D. (Eds), Nubica I/II, Cologne, 653-659

Walter, C. 2003: The Warrior Saints in Byzantine Art and Tradition, Aldershot

Walters, C.C. 1989: Christian Paintings from Tebtunis, JEA 75, 191-208

Waszink, J.H. 1933: Tertullian. De Anima mit Einleitung, Übersetzung und Kommentar, Amsterdam

Woźniak, M. 2013: Iconographie des souverains et des dignitaires de la nubie chrétienne : Les vêtements d'apparat, unpublished $\mathrm{PhD}$ thesis, Université Paris-Sorbonne, Paris

Woźniak, M. 2016: The chronology of the eastern chapels in the Upper Church at Banganarti. Some observations on the genesis of "apse portraits" in Nubian royal iconography, [in:] Łajtar, A., Obłuski, A., Zych, I. (Eds), Aegyptus et Nubia Christiana. The Włodzimierz Godlewski Jubilee Volume on the Occasion of his 70th Birthday, Warsaw, 629-646

Zielińska, D. 2010: The iconographical program in Nubian churches: progress report based on a new reconstruction project, [in:] Godlewski, W., Łajtar, A. (Eds), Between the Cataracts, Proceedings of the 11th Conference of Nubian Studies Warsaw University, 27 August-2 September 2006, PAM Supplement Series 2, part 2, fasc. 2, Warsaw, 643-651

Żurawski, B. 1999: Medieval Nubian Regalia: Innovation versus Tradition, [in:] Welsby, D.A. (Ed.), Recent Research in Kushite History and Archaeology. Proceedings of the 8th International Conference for Meroitic Studies, London, 223-234

Żurawski, B. 2012: St. Raphael Church I at Banganarti, Mid-Sixth to Mid-Eleventh Century. An Introduction to the Site and the Epoch, Gdańsk Archaeological Museum African Reports 10, Monograph Series 2, Banganarti 1, Gdańsk-Włocławek

Żurawski, B. with appendices by Łajtar, A., Piasecki, K., Łaptaś, M., Woźniak, M., Osypińska, M., Cedro, A. 2014: Kings and Pilgrims: Saint Raphael Church II at Banganarti, Mid-Eleventh to Mid-Eighteenth Century, Nubia V, Banganarti 2, Warsaw 


\section{ÉTUDES et TRAVAUX XXXII / 2019}

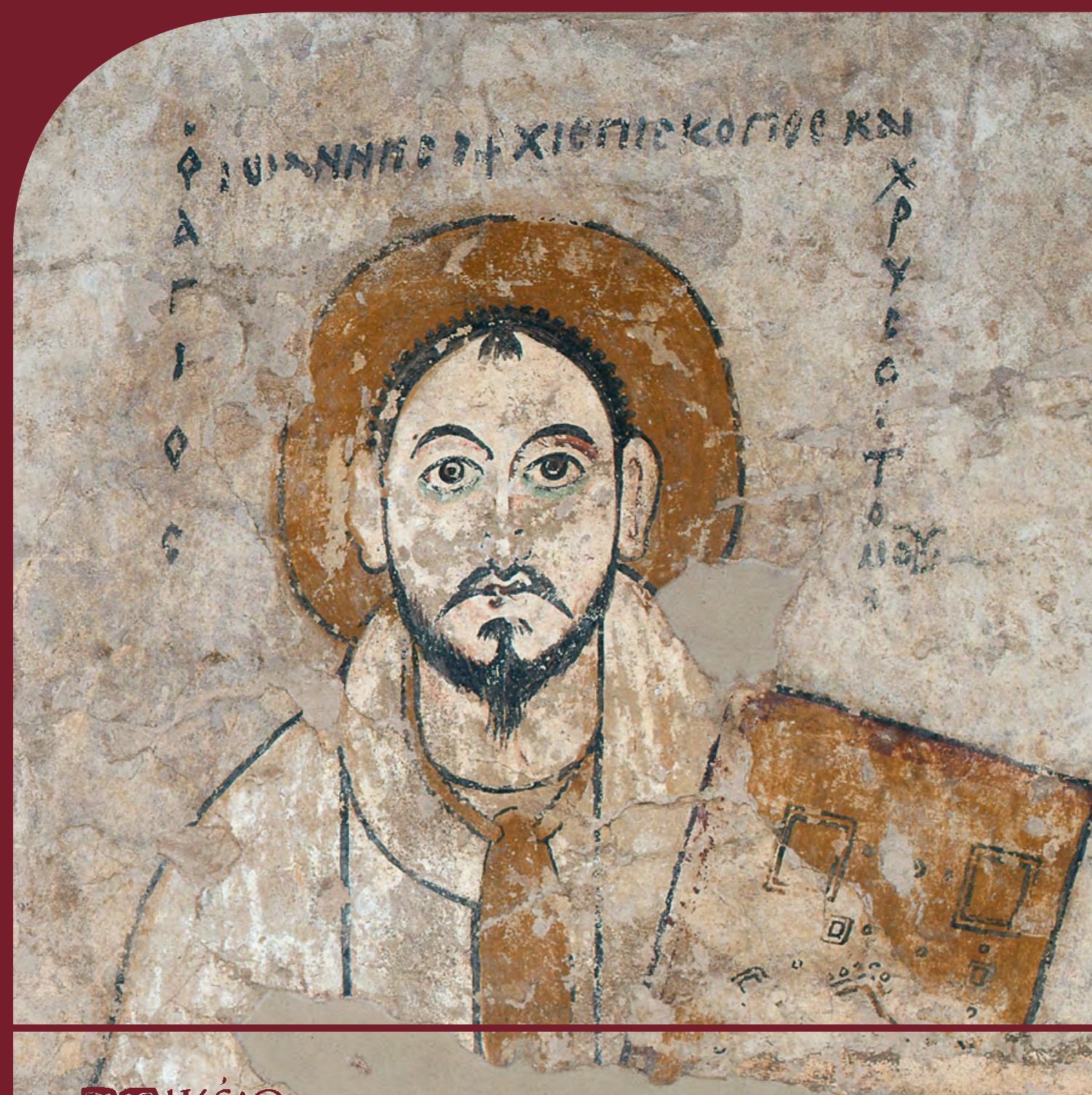

BOMIKSiO Institut des Cultures Méditerranéennes et Orientales ED2A PAN de l'Acácémie Polonaise des Sciences 


\title{
COMITÉ DE RÉDACTION SCIENTIFIQUE
}

Maciej Makowski - rédacteur en chef Jadwiga Iwaszczuk - rédacteur

Maciej G. Witkowski - rédacteur

Agnieszka Ryś - sécretaire de la rédaction

Bogdan Żurawski - rédacteur thématique du volume

CONSEIL SCIENTIFIQUE DU JOURNAL

M. Kobusiewicz (IAE PAN, Warszawa), E. Laskowska-Kusztal (IMOC PAS, Warszawa),

D. Michaelides (University of Cyprus, Nicosia),

J.Ch. Moretti (IRAA-MOM, Université de Lyon 2/CNRS),

D. Raue (Ägyptisches Museum der Universität Leipzig), P. Reynolds (ICREA, España),

D. Welsby (British Museum, London)

\section{COMITÉ SCIENTIFIQUE DE LECTURE}

D.E. Arnold (Wheaton College/The Field Museum, Chicago), H.D. Baker (University of Toronto),

P. Ballet (ArScAn-ESPRI, Université Paris Nanterre), Ch. Barber (Princeton University),

N. Beaux-Grimal (IFAO, Caire/Collège de France, Paris), A. Boud'hors (CNRS, IRHT, Paris),

J. Budka (Ludwig-Maximilians-Universität München), R. David (SFDAS),

A. Delattre (CPEG, Bruxelles), A. Dodson (University of Bristol),

E. Fogliadini (Facoltà Teologica dell'Italia Settentrionale, Milan),

V. Francigny (CNRS/CRES, Paris), L. Gabolde (CNRS), C. Gobeil (Egypt Exploration Society, London),

N. Hamdi (UCL, Louvain), J. den Heijer (CIOL/INCAL, Louvain-la-Neuve),

S. Ikram (American University in Cairo), Ch. Leitz (Universität Tübingen), S. Ortisi (Universität München),

E. Rova (Università Ca' Foscari Venezia), G. Ruffini (Fairfield University),

A. Sasson (San Diego Natural History Museum), H. Satzinger (Universität Wien),

S.M. Schellinger (The Ohio State University, Columbus), G. Schreiber (Eötvös Loránd University, Budapest),

E. Teeter (University of Chicago), S. Torallas-Tovar (University of Chicago),

Y. Tristant (Macquarie University, Sydney), V. Vaelske (independent researcher),

H. Vymazalová (Charles University, Prague), P. Weschenfelder (Universität Wien),

B. Williams (University of Chicago/PCMA UW, Warszawa),

K. Winther-Jacobsen (The Danish Institute at Athens), E. Zacharopoulou (University of Johannesburg),

P. Grotowski (UPJPII, Kraków), E. Papuci-Władyka, J. Śliwa (IA JU, Kraków), A. Ćwiek (IA AMU, Poznań),

K.O. Kuraszkiewicz, M. Pinker (FOS UW, Warszawa), Ł. Niesiołowski-Spanò (IH UW, Warszawa),

M. Gawlikowski, Mahmoud El-Tayeb (PCMA UW, Warszawa), S. Rzepka (IA UW, Warszawa)

\author{
RÉDACTION TECHNIQUE \\ Monika Wesołowska
}

REVUE DES TEXTES ANGLAIS

Jo Harper 
ÉTUDES et TRAVAUX

XXXII 
INSTYTUT KULTUR ŚRÓDZIEMNOMORSKICH I ORIENTALNYCH POLSKIEJ AKADEMII NAUK

\title{
STUDIA i PRACE
}

\author{
XXXII
}

gू IKŚiO

ESAN

WARSZAWA

2019 
INSTITUT DES CULTURES MÉDITERRANÉENNES ET ORIENTALES DE L’ACADÉMIE POLONAISE DES SCIENCES

\section{ÉTUDES et TRAVAUX}

XXXII

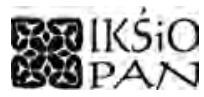

VARSOVIE

2019 
Publication scientifique financée dans le cadre du programme du Ministre de la Science et de l’Éducation Supérieure

« Programme National de Développement de l’Humanistique » pour les années 2016-2021 (projet no $3 b H 150099$ 83)

\title{
TI NARODOWY PROGRAM ROZWOJU HUMANISTYKI
}

\author{
Copyright $(\mathbb{C}$ \\ Instytut Kultur Śródziemnomorskich i Orientalnych PAN \\ et les Auteurs \\ Warszawa 2019
}

\begin{abstract}
ISSN 2084-6762
(avant 2011 : 0079-3566)

e-ISSN 2449-9579

Version première en papier, imprimée en Pologne - 150 copies

Version électronique accessible sur

http://www.etudesettravaux.iksiopan.pl
\end{abstract}

Édition: Polskie Towarzystwo Historyczne et Wydawnictwo Neriton, Warszawa

Conception générale de couverture : J. Iwaszczuk

Photo de couverture : P. Ligier ; courtoisie du Musée National de Varsovie

(Saint Jean Chrysostome, peinture, cathédrale de Faras). 


\section{Table des matières}

Editorial: Quid novi ex Nubia (par Bogdan Żurawski) ............................................... 7

Bibliography of Professor Stefan Jakobielski ................................................................ 13

Aneta Cedro, Bogdan Żurawski

Living with the Past in Modern Sudanese Village. Traditional Pottery Production

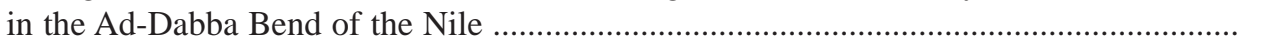

DAVID N. EDWARDS

A Possible Monastery and the 'Upper Maqs’ at Ukma-Akasha West? ............................ 53

Vincent W.J. van GeRven OeI

An Old Nubian Curse from the Faras Cathedral ........................................................ 81

Vincent W.J. van Gerven Oei, Adam Łajtar

Two Old Nubian Inscriptions from Akasha West ........................................................ 89

Vincent W.J. van Gerven Oei, Alexandros Tsakos

Rubrication Patterns in Two Old Nubian Manuscripts from Serra East .......................... 99

KAREL C. INNEMÉE

A Man in a Vessel, Once More .................................................................................. 111

KAREL C. INNEMÉE, Dobrochna ZielińSKA

Faces of Evil in Nubian Wall-Painting - An Overview ................................................ 121

ADAM ŁAJTAR

Epitaph of Merki Found in Hambukol ....................................................................... 145

MAGDALENA ŁAPTAŚ

Attributes, Vestments, Context and Inscription in the Identification of Nubian

Paintings: Proposing the 'Multi-Layer' Image Recognition Method ............................... 161

Grzegorz Ochala

Nubica Onomastica Miscellanea I: Notes on and Corrections to Personal Names

Found in Inscriptions from Faras 


\section{Robin SEIGNOBOS}

L'influence du Kitāb ahbār al-Nūba d'Ibn Sulaym al-Uswānī sur l'Histoire des églises et monastères d'Égypte d'Abū al-Makārim

JACQUES VAN DER VLIET

Exit Bishop Tamer - the Sequel. A New Edition of the Epitaph of Papsine alias Doulista (DBMNT 78) 